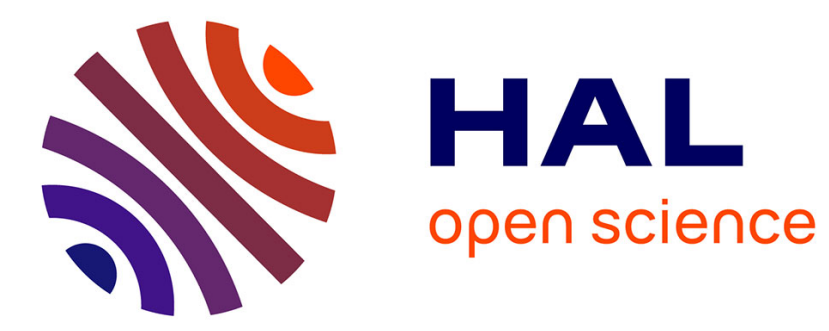

\title{
François Garin: Pioneer work in catalysis through synchrotron radiation
}

Dominique Bazin

\section{To cite this version:}

Dominique Bazin. François Garin: Pioneer work in catalysis through synchrotron radiation. Comptes Rendus. Chimie, 2014, 17 (7-8), pp.615 - 624. 10.1016/j.crci.2013.10.002 . hal-01018306

\section{HAL Id: hal-01018306 https://hal.science/hal-01018306}

Submitted on 4 Jul 2014

HAL is a multi-disciplinary open access archive for the deposit and dissemination of scientific research documents, whether they are published or not. The documents may come from teaching and research institutions in France or abroad, or from public or private research centers.
L'archive ouverte pluridisciplinaire HAL, est destinée au dépôt et à la diffusion de documents scientifiques de niveau recherche, publiés ou non, émanant des établissements d'enseignement et de recherche français ou étrangers, des laboratoires publics ou privés. 
François Garin: pioneer work in catalysis through synchrotron radiation

\author{
D. Bazin \\ CNRS - LCMCP - UPMC \\ Collège de France, 11 place M. Berthelot, 75005 Paris Cedex
}

\begin{abstract}
Starting from the late seventies, the progressively increased availability of beamlines dedicated to X-ray absorption spectroscopy allowed the execution of experiments in chemistry. In this manuscript, I describe the contribution of F. Garin at the frontier of heterogeneous catalysis and synchrotron radiation. Working at LURE as a scientific in charge of a beamline dedicated to X-ray absorption spectroscopy during almost twenty years and thus having the opportunity to discuss with research groups working in heterogeneous catalysis in Europe as well as in United states, it was quite easy to show that his work is clearly at the origin of current research in heterogeneous catalysis, not only in France, but in different synchrotron radiation centers.
\end{abstract}

\title{
1. Introduction
}

Heterogeneous catalysis is now a major research subject in different synchrotron radiation facilities. The starting point of this success story began with one of the first publications by the fathers of the modern X-ray absorption spectroscopy (XAS), D.E. Sayers, F.W. Lytle and E.A. Stern [1]. In this paper [2], the authors presented normalized data from a variety of pure metals, semiconductors, inorganic and organometallic compounds, and dilute transition metal catalysts on $\mathrm{Al}_{2} \mathrm{O}_{3}$ supports. For a $4 \% \mathrm{wt}$ Co on alumina, they noticed a tetrahedrally coordination. With catalyst characterization, the cornerstone of catalysis science, the scientific highway was open.

Subsequently, several investigations were performed by outstanding chemists (see for example references 3 to 8 , a list which is far from exhaustive). Now, it is quite exciting to notice that other young outstanding chemists have obtained also very interesting results. Among these outstanding chemists, F. Garin and G. Maire have been instrumental in developing heterogeneous catalysis in France [9]. With a background in surface science [10], they combined XAS with labelled compounds, a sophisticated technique able to bring invaluable information about the reaction's mechanisms [11-16]. Such an original approach constitutes the signature of different investigations performed in the laboratories of $\mathrm{F}$. Garin and G. Maire (from the Laboratoire d'Etudes de la Réactivité Catalytique, des Surfaces et Interfaces or LERCSI, to the Laboratory on Materials, Surfaces and Processes for Catalysis or LMSPC at the University of Strasbourg). This research has played and continues to play a pivotal role in heterogeneous catalysis. Finally, I had the great honour and pleasure to discuss this research with F. Garin at the Laboratoire pour l'Utilisation du Rayonnement Electromagnétique (LURE).

In this manuscript, devoted to the research by F. Garin, I describe some of his contributions at the frontier of heterogeneous catalysis and synchrotron radiation and try to show how this research is clearly at the origin of current research in heterogeneous catalysis. To attain this goal, I begin by recalling briefly some basic features of XAS. 


\section{X-ray absorption spectroscopy}

Among the different techniques related to synchrotron radiation, XAS has a particular place [1]. XAS encompasses both X-ray Absorption Near Edge Structure (XANES) and Extended X-ray Absorption Fine Structure (EXAFS). The first absorption spectra were recorded at the beginning of the $20^{\text {th }}$ century [17], but understanding the physics of EXAFS began just 4 decades ago. The basic model seems quite simple : The absorption of an X-ray photon by an atom ejects a photoelectron, which is scattered by neighbours. An interference process builds up between the wave function of the outgoing electron and its scattered parts. Following the X-ray absorption edge, this interference process leads to a modulation of the absorption coefficient.

In terms of heterogeneous catalysis, at the $\mathrm{L}_{\mathrm{III}} \mathrm{X}$-ray absorption edge, a phenomenon discovered a long time ago called the "white line" is often observed [18]. Numerous excellent publications are based on the increased intensity of the white line when Pt is oxidized [19-25]. With nanometer-scale metallic clusters, two physical phenomena can affect the intensity of the white line: the size of the cluster, considered as an intrinsic effect (density of the state of the nanometer-scale platinum cluster is far from that of the bulk one), and a possible charge transfer between the cluster and the support, considered as an extrinsic effect $[26,27,28]$.

Finally, a Fourier transform (FT) of the EXAFS spectrum in terms of photoelectron wave number will show peaks at distances corresponding to the nearest-neighbor atomic coordination shells (Figure 1). Thus, the analysis is based on a simple FT relationship between $\chi(\mathrm{k})$ and the radial distribution function around the central atom [29]. Note that XAS is insensitive to polydispersity [30,31].

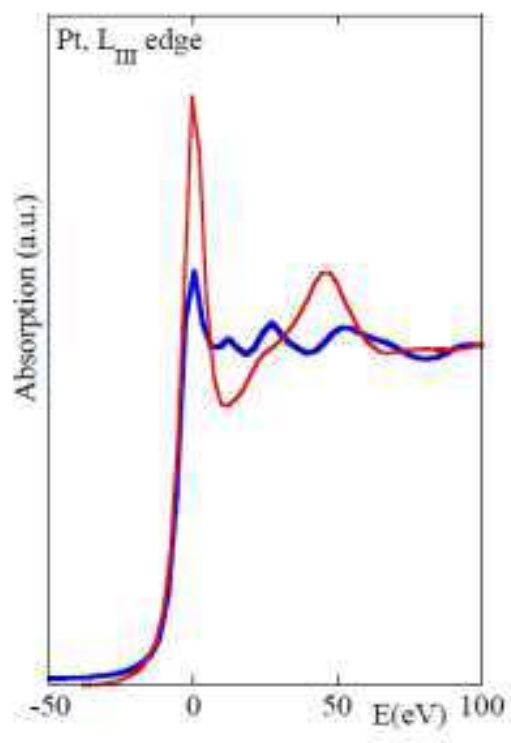

(A)

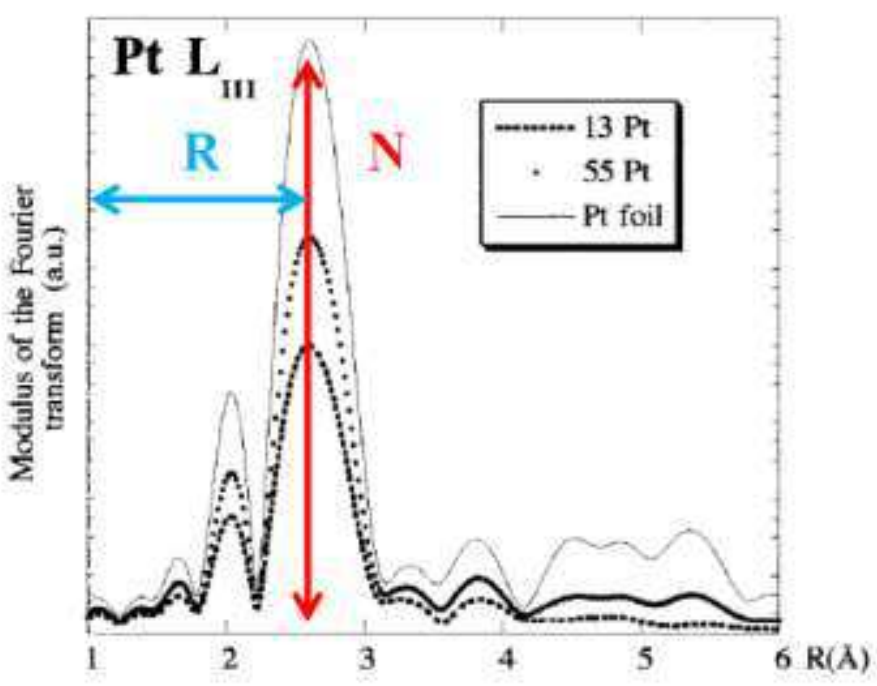

(B)

Fig. 1. (A) White line intensity of $\mathrm{PtO}_{2}$ (red) and the Pt metallic foil (blue). (B) Modules of the Fourier transform associated with clusters of 13 and 55 platinum atoms compared to modulus of platinum metallic foil. The amplitude of the modulus is related to the average coordination number and the position is related to the inter-atomic distance.

In heterogeneous catalysis, even if most of these investigations have been performed using photons whose energy lies in the range between 3 and $25 \mathrm{keV}$, it is worth to underline that different results based on the analysis of soft X-ray spectra collected either at the K-edge of light elements [32-36] or at the L- and M-edges of transition metals [37-42] have been 
obtained. For example, quite exciting results have been described recently by $\mathrm{S}$. Carenco et al. [43] regarding the $\mathrm{CuCo}$ bimetallic system. These authors show that the structure and composition of core-shell $\mathrm{CuCo}$ nanoparticles were found to change as a result of cleaning pretreatments and when exposed to syngas $\left(\mathrm{CO}+\mathrm{H}_{2}\right)$ at atmospheric pressure.

The advantages of the EXAFS technique have been well discussed [44-48] but an elegant way to present the capabilities of this spectroscopy was given in one of the first publications dedicated to EXAFS spectroscopy [49].

\section{Structural characterization with EXAFS at the atomic level}

The first advantage of the EXAFS technique is related to measurement of the shortrange order around a species of atoms in both periodic and nonperiodic arrangements. Amorphous as well as nanometer-scale metallic and non-metallic compounds have been widely investigated by EXAFS spectroscopy. International congresses have been dedicated to research using this spectroscopy and its applications in physics, chemistry, and biology.

Regarding heterogeneous catalysis, numerous catalytic systems have been investigated with XAS. Among them, the most popular is probably the monometallic $\mathrm{Pt} / \mathrm{Al}_{2} \mathrm{O}_{3}$ [50,51]. Because each kind of metal present in the catalyst can be measured separately, different bimetallic catalytic systems have been considered [52-56].

Figure 2 shows X-ray absorption spectra for the bi-metallic system $\mathrm{IrCo} / \mathrm{Al}_{2} \mathrm{O}_{3}$ [52]. The sample contained $6.5 \%$ weight metal and 35.5 atomic $\%$ Ir prepared by co-impregnation with $\mathrm{H}_{2} \mathrm{IrCl}{ }_{6}$ and $\mathrm{Cu}\left(\mathrm{NO}_{3}\right)_{2}$ solutions. For XAS, the catalyst was placed in a continuous-flow cell equipped with a cooled trap to keep the hydrocarbon pressure constant during the catalytic experiments ( 6 Torr for 2-methylpentane). By means of a catharometer inserted in the flow line, the pressure-versus-time curve and hydrocarbon flow rate were determined. Samples for gas liquid chromatography (GLC) analysis were extracted directly from the gas phase by use of a gas syringe as the pulse passed a rubber septum located close to the reactor. At the exit of the reactor, a liquid nitrogen trap was used to collect the products of the reactions. For 13C-labelled experiments, isomerized products were analysed by GLC mass spectrometry. Such experiments thus represent the first example of structural characterization by XAS combined with a technique able to assess the mechanism of the chemistry.

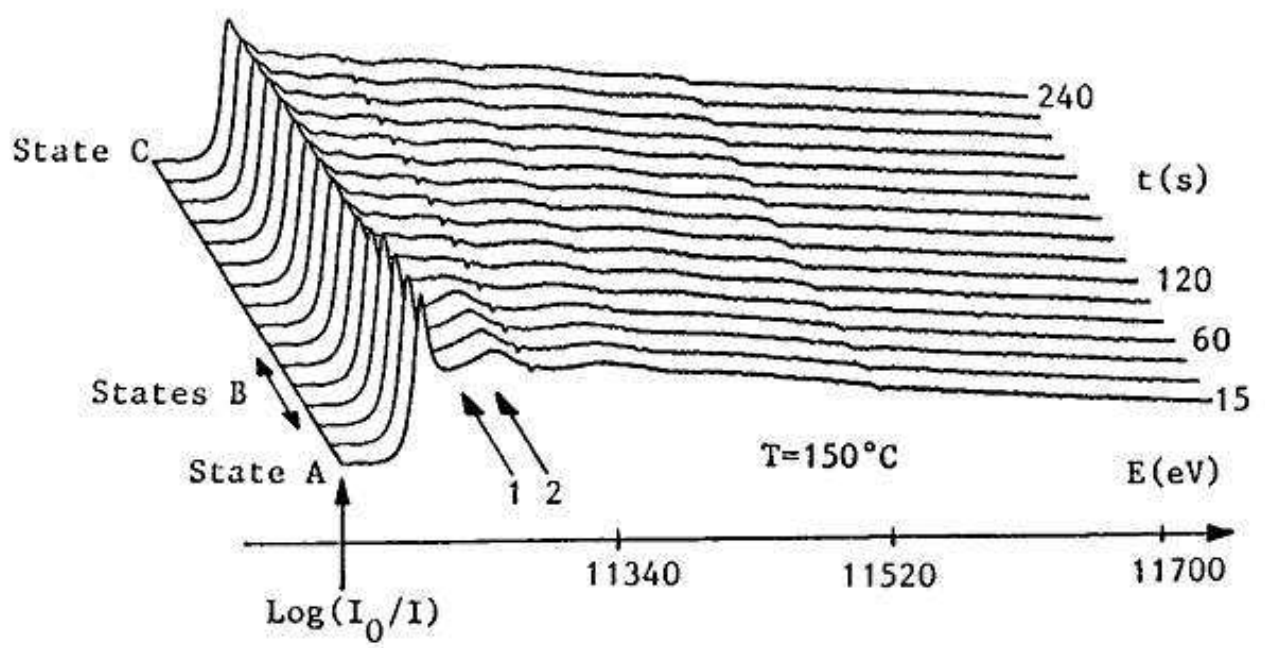

Fig. 2. Absorption versus energy and time at the $\mathrm{Ir} \mathrm{L}_{\mathrm{III}}$ edge during reduction at $150^{\circ} \mathrm{C}$. State $\mathrm{A}$ is the starting material and state $\mathrm{C}$ the reduction step. State $\mathrm{B}$ defines the transition of cation to metal by (1) a reduction in the white line and (2) a change in the frequency of EXAFS oscillations. 
Of note, a publication by F. Garin is at the core of this research. Using contact reactions of $\mathrm{C} 6$ hydrocarbons (isomerization, dehydrocyclization and hydrocracking), Garin et al. [57,58] studied under the same experimental conditions, $\mathrm{Pt} / \mathrm{Al}_{2} \mathrm{O}_{3}$ catalysts of low and high dispersion as well as different well-characterized surfaces: $\operatorname{Pt}(557), \operatorname{Pt}(119)$ and $\operatorname{Pt}(111)$. The behaviour of the monometallic catalyst $\mathrm{Pt} / \mathrm{Al}_{2} \mathrm{O}_{3}$ at low dispersion could be well simulated by such platinum surfaces. In contrast, the particular properties of the highly dispersed $0.2 \mathrm{wt} \%$ $\mathrm{Pt} / \mathrm{Al}_{2} \mathrm{O}_{3}$ catalyst were never simulated by single crystals of platinum. A quick analysis of the numerous publications of $\mathrm{Pt} / \mathrm{Al}_{2} \mathrm{O}_{3}$ catalysts shows that XAS gives invaluable information on the cluster morphologic features, the modification of the interatomic distance [59] or the particle-growing process during the reduction step [60,61].

Regarding the description of the first coordination sphere around one specific atom, the authors of an early paper [49] assessed the discrimination between several types of surrounding atoms. In heterogeneous catalysis, this property allows the following of the different steps of the preparation procedure, that is, impregnation, calcination, and reduction by discriminating between $\mathrm{Pt}-\mathrm{Cl}, \mathrm{Pt}-\mathrm{O}, \mathrm{Pt}-\mathrm{Pt}$ as well as $\mathrm{Pt}-\mathrm{M}$ ( $\mathrm{M}$ being a transition metal) bonds [62-64].

The possibility of distinguishing distances parallel and perpendicular to the surface by the use of polarized X-rays was shown in the publication by $\mathrm{K}$. Asakura et al., which describes precisely the structure transformation of Pt clusters on $\mathrm{Al}_{2} \mathrm{O}_{3}(0001)$ [65]. The authors noted that raft-like Pt clusters were stabilized by the formation of direct Pt-O-Al bonding with the $\alpha-\mathrm{Al}_{2} \mathrm{O}_{3}$ surface.

The determination of the chemical state of the atom by the edge shift and near-edge structure is one of the current major developments in XAS. For such nanometer-scale entities, their XANES spectra cannot be simulated for K or L edges by a linear combination of the XANES spectra of well-crystallized reference compounds [27,28,66].

Finally, in a relatively simple interpretation of EXAFS spectrometry, multiple scattering effects are exactly zero in a FT analysis of the first-neighbor shell and usually negligible for the next few shells. With the development of the FeFF package, the multiple scattering effect can be well evaluated in different structures [27,28,35,66,67]. In fact, several investigations have underlined the advantages of combining XAS and anomalous X-ray wideangle scattering to characterize the environment after the first-neighbor shell [68-78].

\section{Preparation protocols and chemotherapy}

A parallel can be revealed between the paper of F. Garin dedicated to the preparation protocol of a catalyst [49] and chemotherapy. Pt is part of a classical catalyst and also at the core of chemotherapy. As underlined by A.V. Klein and T.W. Hambley [79], the era of platinum-based anticancer drugs was heralded by the clinical introduction of cisplatin, a square-planar $\mathrm{Pt}(\mathrm{II})$ complex with antitumor properties. The success of cisplatin paved the way for the second- and third-generation platinum (II) drugs, carboplatin and oxaliplatin.

In heterogeneous catalysis, the preparation is a key step to optimize the selectivity and the reactivity. In particular, the morphology and dispersion of metal clusters can be affected by the preparation method. It can be generally divided into 3 steps [80-88]. During the impregnation of the active element, isolated complex ions at the open surface of the oxide platelets are fixed. Then, the purpose of drying and calcination steps is to eliminate the water as well as many different anions from the precursor $\left(\mathrm{Cl}^{-}, \mathrm{NO}^{-}\right.$, etc.). Finally, the reduction under hydrogen results in a nanometer-scale metallic cluster at the oxide surface. The impregnation step is performed in solution by competition between $\mathrm{H}_{2} \mathrm{PtCl}_{6}$ and chloride acid.

In chemotherapy, the stability of platinum-based anticancer drugs in the presence of chloride ions, provided under perfusion conditions, has been also studied [89-92]. 
Additionally, in response to the significantly lowered chloride ion concentration found inside cells (3-20 mM), cisplatin is activated intracellularly by aquation of one of its two chloridoleaving groups [79].

Another parallel between heterogeneous catalysis and chemotherapy is given by the formation of $\mathrm{Pt}-\mathrm{S}$ bonds. Platinum-based anticancer drugs can bind to thiol-containing biomolecules, thus leading to the deactivation of platinum drugs [89-92]. Such deactivation is also well known in reforming to decrease the high hydrogenolysis activity $[93,94]$.

Thus, some research has investigated catalytic as well as anticancer properties of $\mathrm{Pt}$ species. Also, it is worth to mention that a recent publication of S. Gómez-Ruiz et al. [95] was dedicated to a novel alkenyl-substituted ansa-zirconocene complex with dual application as an olefin polymerization catalyst and anticancer drug. Regarding the characterisation techniques, numerous investigations have examined platinum-based anticancer drugs with XAS [89-92, 96-98].

Finally, catalysis processes are involved in different research subjects related to health problems [99-110], and the very first experiments performed at the French national synchrotron facility SOLEIL (Source Optimisée de Lumière d'Énergie Intermédiaire du LURE) [111] on the DIFFABS beamline [112] involved a catalytic problem assessed by XAS $[113,114]$.

\section{Sample environments}

As underlined by S.R. Bare et al. [115], the cell developed by Lytle et al. [116] at the beginning of the age of synchrotrons (the late 1970s) in collaboration with the Exxon research group was a mile stone for in situ XAS characterization of catalysts. F. Garin and his research group understood quickly that for a breakthrough in heterogeneous catalysis, it was not necessary to decrease the sample temperature in order to increase the signal-to-noise ratio for $\mathrm{X}$-ray absorption spectra but rather to collect data during the chemical reactions [52]. Therefore, it was of a prime importance to develop sample environments to mimic chemical reactions. Figure 3 displays a general view of the EXAFS IV beamline on which the reactor cell developed for post-combustion and used in different $\mathrm{PhD}$ theses under the direction of $\mathrm{F}$. Garin is positionned. We can see clearly the different parts of the experimental set-up with a device dedicated to increase the temperature of the samples to $700^{\circ} \mathrm{C}$. An examination of the literature shows that several devices to control the gas mixture that goes through the catalysts have been developped [117-128].

Such experimental set-ups have gathered significant structural information through XAS during the chemical reaction. Therefore, the activity and reactivity of the catalyst could be associated with structural characteristics of nanometer-scale metallic clusters deposited at the surface of oxides with large specific surface. The development of the different reactor cells at LURE was clearly promoted by the investigations performed by F. Garin. Thanks to this pioneer work, it is now possible to collect XAS data at a high pressure with $\mathrm{H}_{2}[129,130]$. 


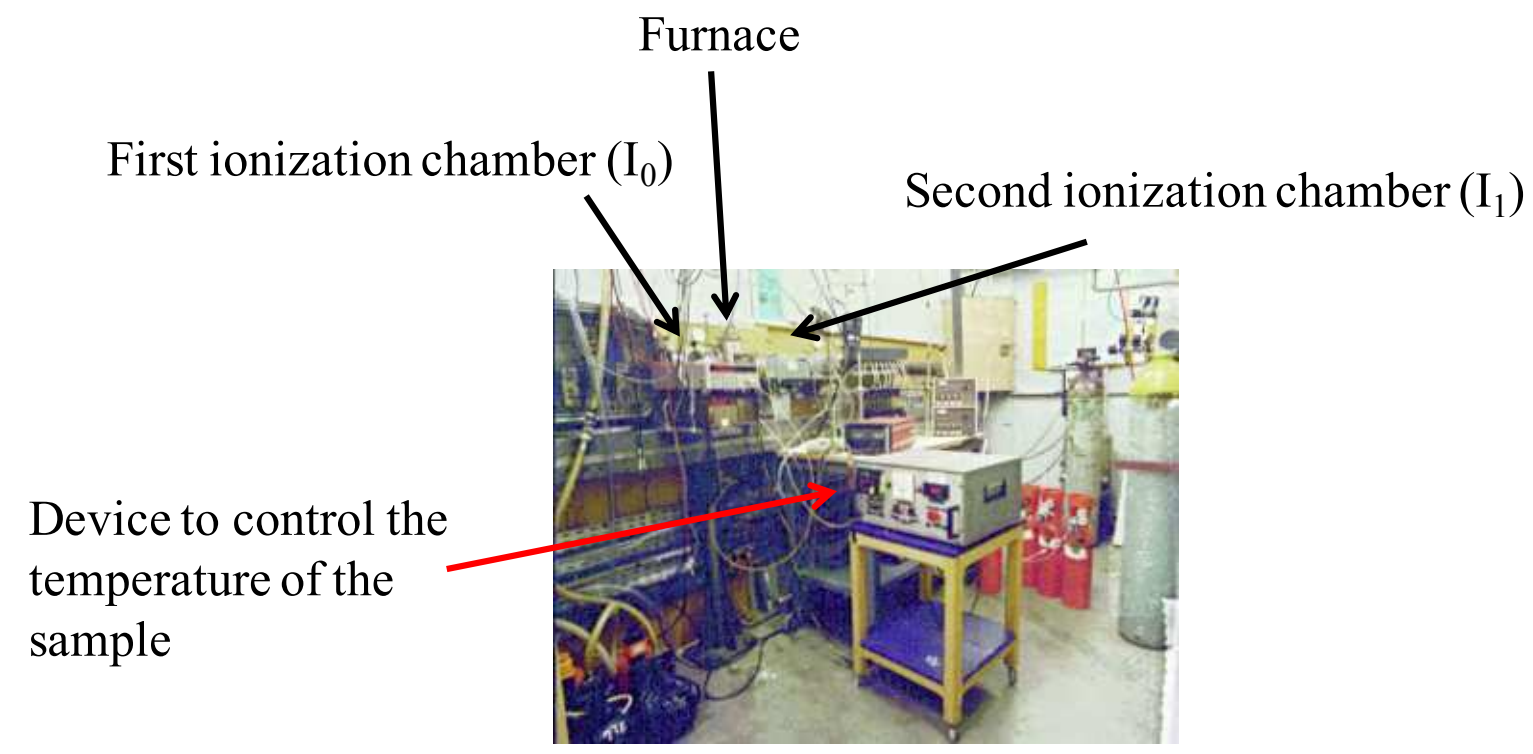

Fig. 3. General view of the EXAFS IV beamline with the reactor cell.

At this point, it is worthy to assess the different scientific breakthroughs obtained by the group of J.D. Grunwaldt [131-136]. This group have also emphasized that catalyst should be ideally present as powder or shell-impregnated particles and the catalytic activity should be simultaneously measured on-line [137]. In another set of exiting experiments, this research group proved that spatiotemporal X-ray absorption is a powerful tool for the elucidation of the coupling of physical and chemical processes occurring in a catalytic reactor with prominent gradients with characteristic changes in X-ray absorption of the respective transition metals [138].

\section{Following the chemical reaction "in real time"}

Moreover, the publication on Ir catalysts [50] opened new opportunities in heterogeneous catalysis in terms of kinetics. In Figure 4, the original experimental set-up related to the EXAFS in the dispersive mode as developed by E. Dartyge and A. Fontaine is shown [139-140]. In the first set of experiments dedicated to the Ir catalytic systems, all spectra were continuously collected. Even with a count time of $15 \mathrm{~s}$ per spectrum, major insights have been assessed on this catalytic system in terms of the reduction step. 


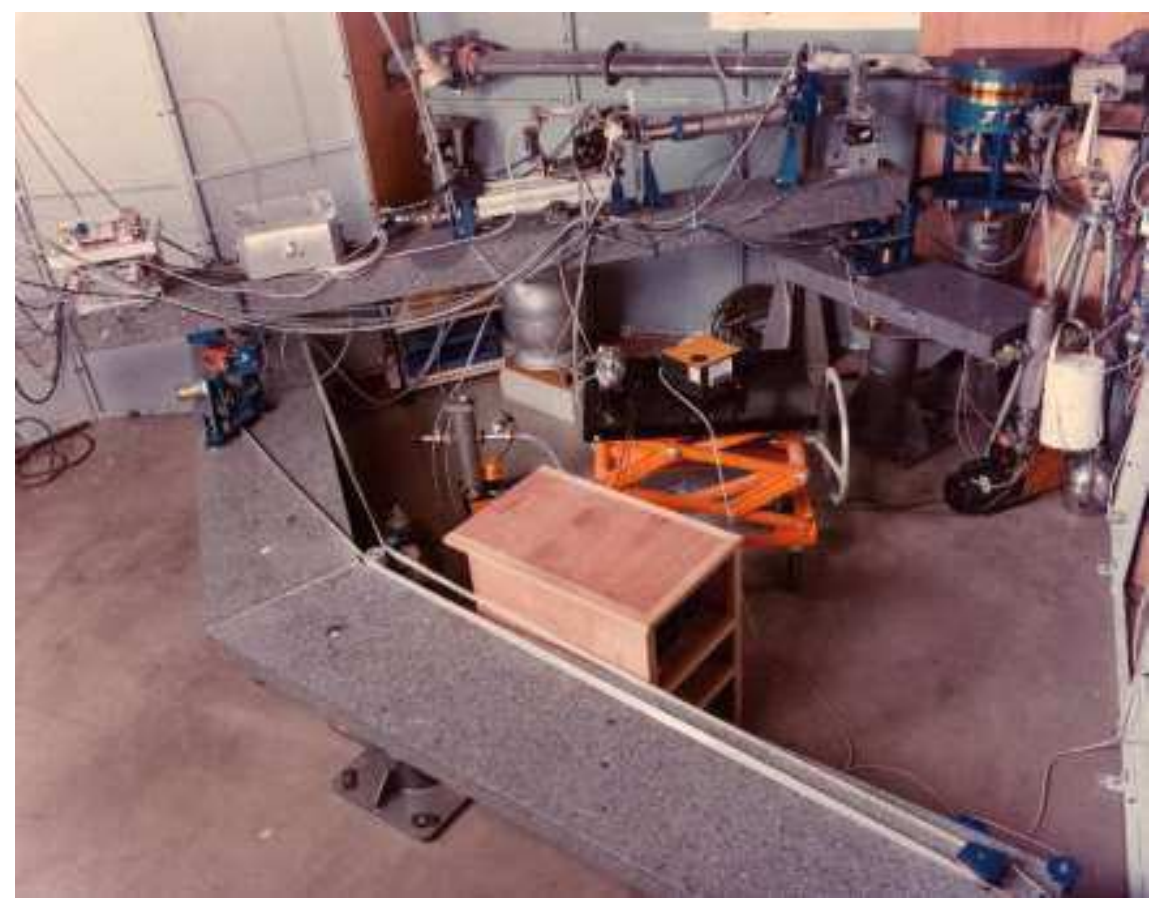

Fig. 4. General view of first "EXAFS dispersive" experimental set-up as developped by E. Dartyge and A. Fontaine

Numerous excellent studies have resulted from experiments performed on the dispersive EXAFS beamline [141-149]. Now, with the synchrotron SOLEIL, the kinetics of chemical reaction can be followed on 2 beamlines, namely "SAMBA," with the "Quick EXAFS beamline" [150-152], and "ODE", the new "EXAFS dispersive" experimental set-up [153-155].

Different major scientific breakthroughs have been achieved using of Quick EXAFS [156-168]. As underlined by R. Frahm [169], this new approach significantly reduces data collection time as compared with the classical step-by-step technique. With the Quick EXAFS beamline at SOLEIL, for each second, 2 spectra of 4800 points can be obtained with an average energy step of $0.25 \mathrm{eV}$ and an integration time of $104 \mathrm{~ms}$ for each point (Figure 5).

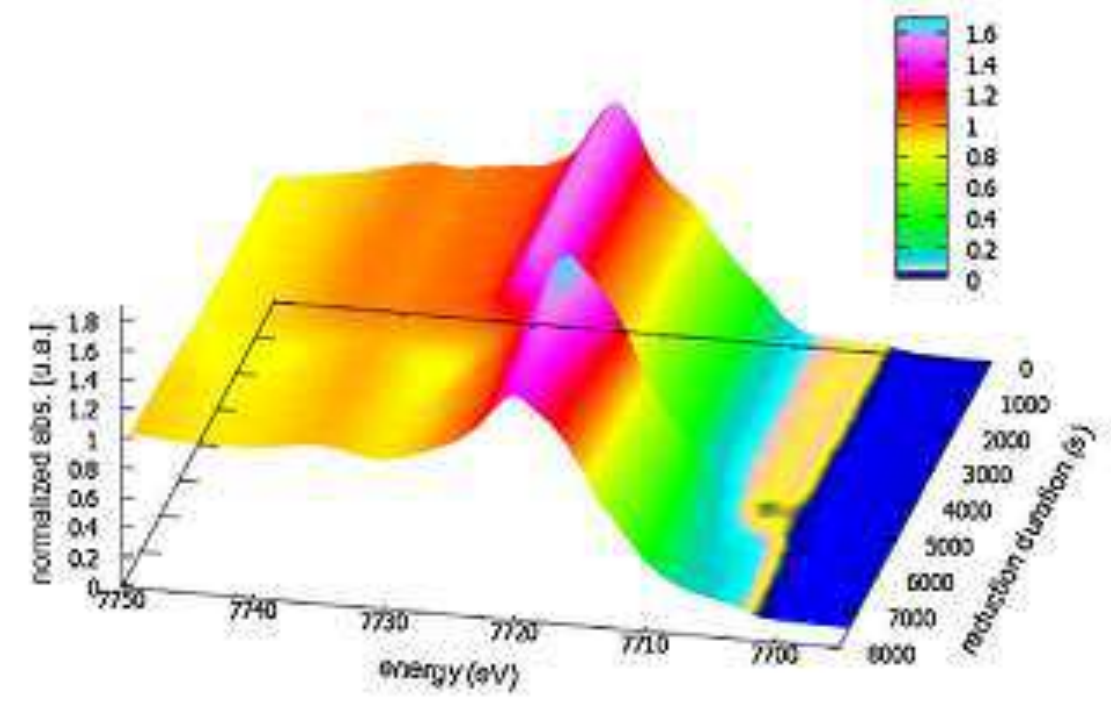

Fig. 5. XANES spectra collected during activation of the catalyst in the XAS cell (100 s for acquisition time) 
One main advantage of this beamline is related to the possibility of recording EXAFS data up to 1000. eV or more at any edge covered by the beamline (from the Ti to Cs K edges). This specificity is illustrated in Figure 6 from recent publications [150,151], which reports on the simultaneous collection of the $\mathrm{L}_{\mathrm{III}}, \mathrm{L}_{\mathrm{II}}$ and $\mathrm{L}_{\mathrm{I}}$ edges of a $5 \mathrm{~d}$ oxide.

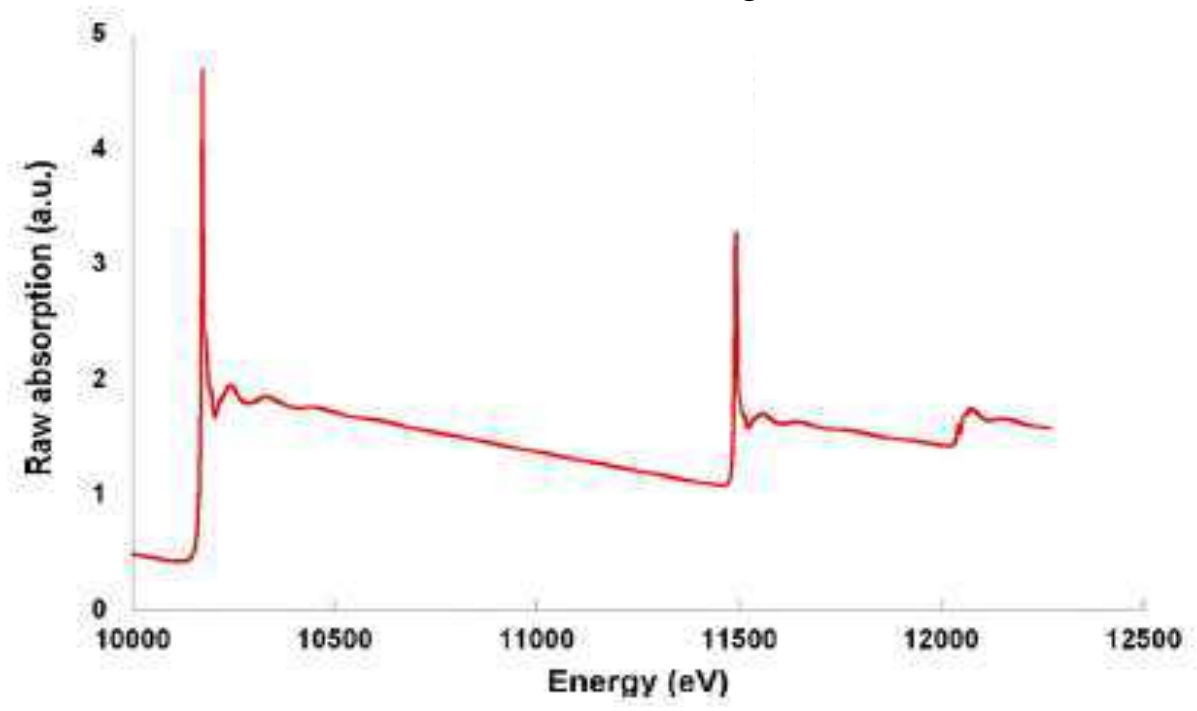

Fig. 6. W L edges of a $\mathrm{Na}_{2} \mathrm{WO}_{4}$ sample acquired in $500 \mathrm{~ms}$ and averaged over 10 spectra.

Such opportunity can be interesting for Pt based bi-metallic systems [170,171] such as PtCo [172-174], PtCu [175], PtPd [176-178], PtRu [179], PtRe [180], PtSn [181] or other bimetallic systems such as PdAu [182], CuCo [183], RuCo [184], ReCo [185], IrPd [186], CoMo[187] or MoW[188]. For example, in the case of the bi-metallic PtRe system [189,190], figure 7 shows X-ray absorption spectra collected between $11400 . \mathrm{eV}$ and $12100 . \mathrm{eV}$, at the Pt $\mathrm{L}_{\mathrm{III}}$ and $\mathrm{Re} \mathrm{L}_{\mathrm{II}}$ edges which are clearly identified (Figure $7 \mathrm{a}$ ). The evolution of the white line intensities of the 2 metals give invaluable information regarding the composition of the nanometer-scale bi-metallic clusters [189] and therefore can be easily used for other bimetallic systems (Figure 7b).
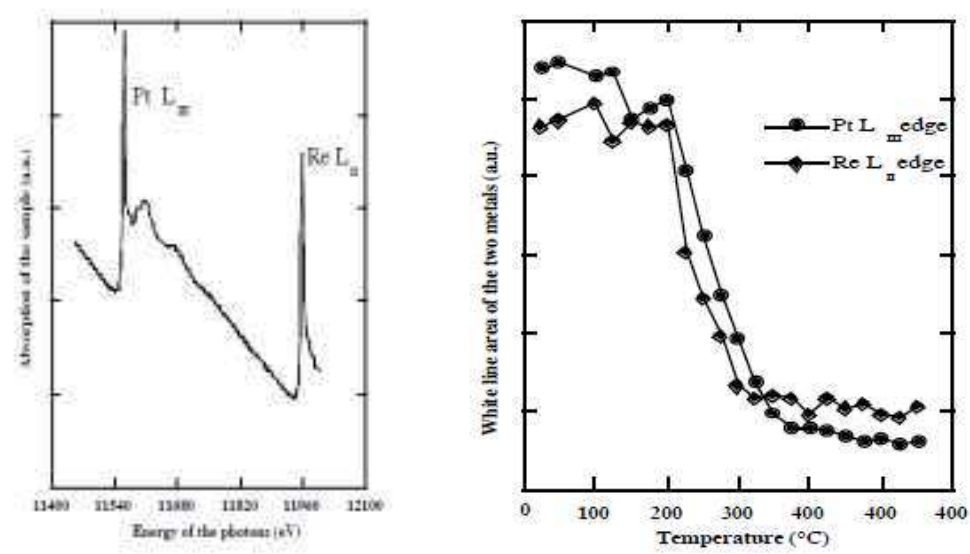

Fig. 7. (a) Absorption spectra collected during in situ reduction of the $1 \%$ wtPt-1\%wt $\mathrm{Re} / \mathrm{Al}_{2} \mathrm{O}_{3}$ sample. (b) Evolution of the white line intensities of the 2 metals (Pt and $\mathrm{Re}$ ) during reduction of the hydrated sample $\mathrm{A}$.

For chemical reactions associated with short reaction times, the EXAFS in the dispersive mode is used. Recently, EXAFS data (Figure 8) were collected on the ODE beamline, with snapshots every $60 \mathrm{~ms}$ during the chemical reaction, then averaged for 100 times along the reaction for better signal-to-noise ratio which reduces the time resolution to 6 
ms $[154,155]$. The new experimental set-up for chemical reactions with short reaction times (Figure 9) greatly differs from the original one and can be used for multipurpose sample environments adapted to various kinds of studies: pressure, temperature, magnetic fields, and gas environments [see for example ref 191-194].

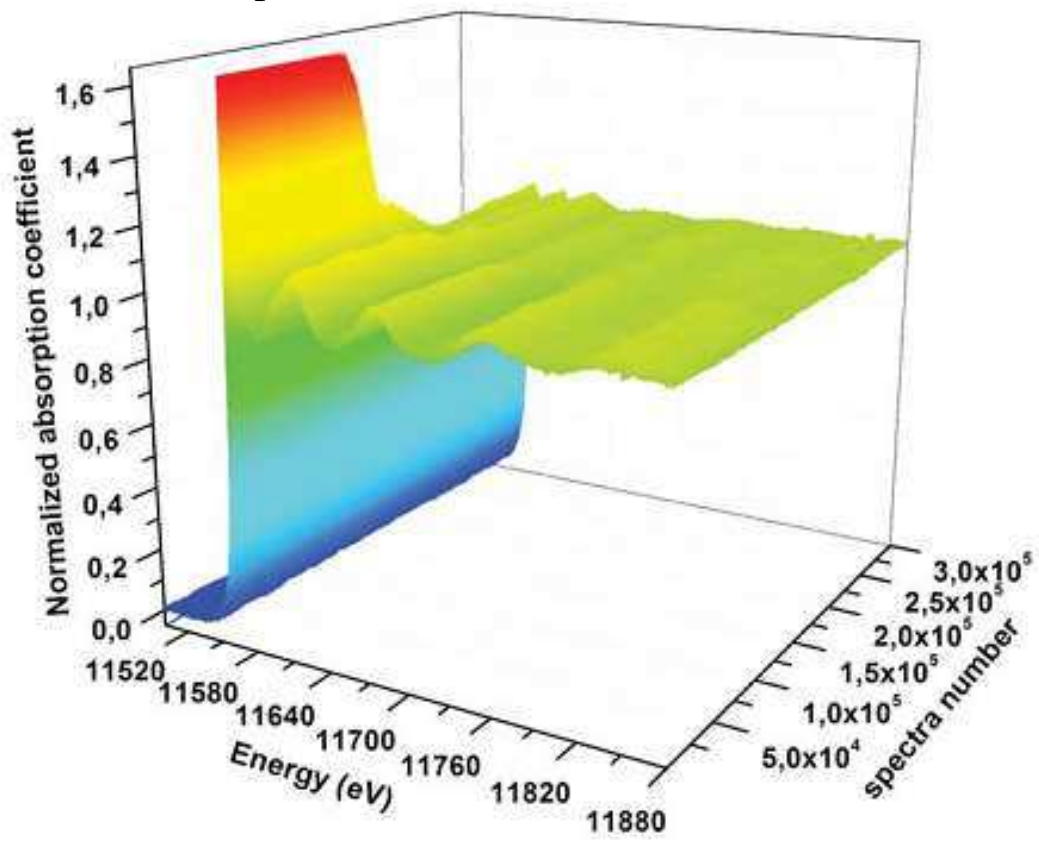

Fig. 8. Experimental EXAFS spectra used to follow the reaction dynamics of the thermolysis of $\left(\mathrm{NH}_{4}\right)_{2} \quad\left[\mathrm{PtCl}_{6}\right]$. The averaged $3 \times 10^{5}$ EXAFS spectra with time resolution of $6 \mathrm{~ms}$, illustrating continuous evolution of EXAFS signal during the reaction.

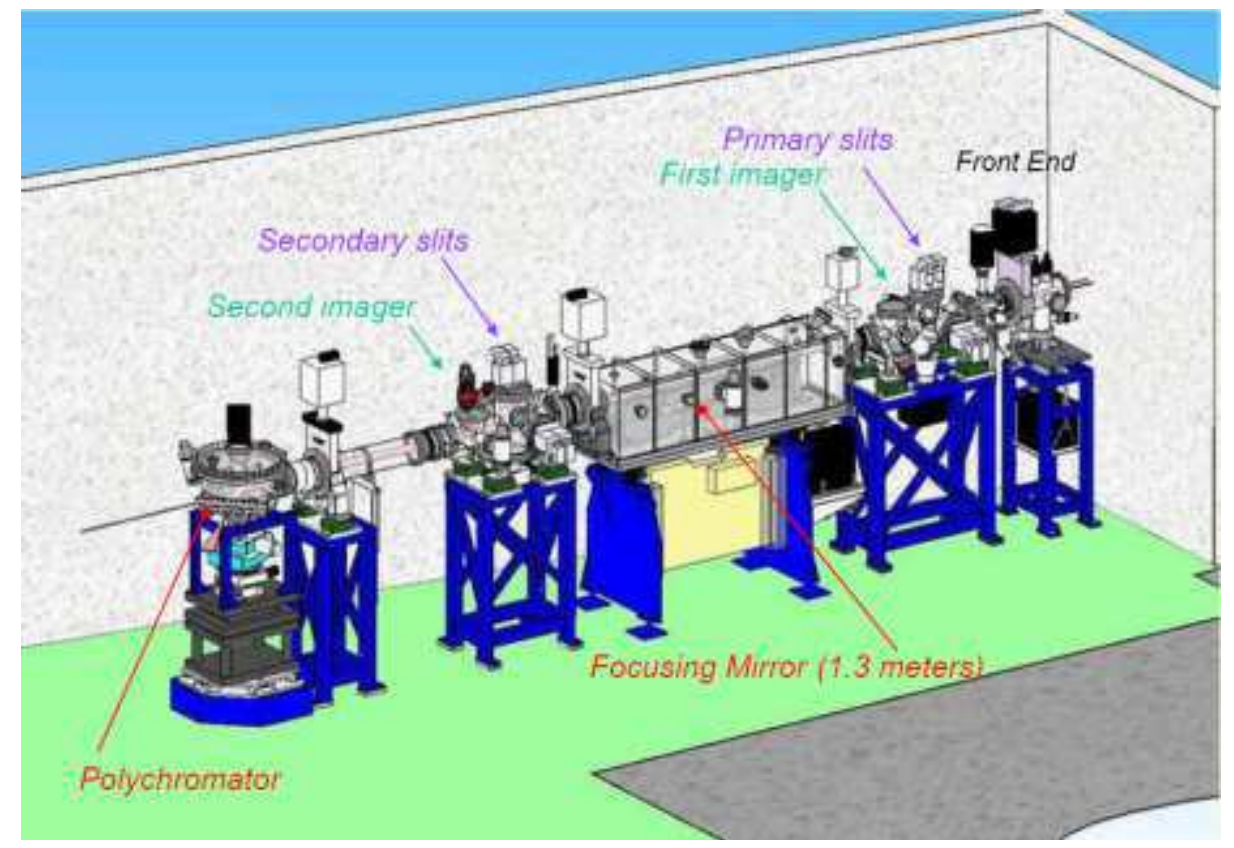

Fig. 9. Schematic view of the new experimental set-up for chemical reactions with short reaction times

Regarding kinetics, quite recent experiments have studied the first few picoseconds of the NO dissociation and the reaction between CO and NO on an iridium surface $[195,196]$. Also, F. Thibault-Starzyk et al. [197] have investigated the $\mathrm{CO}+\mathrm{NO}$ reaction on $\mathrm{Ag} / \mathrm{Al}_{2} \mathrm{O}$ 
through experiments combining femtosecond laser pulses to heat catalysts for nitrogen oxide removal and Fourier transform infrared spectroscopy to determine the chemical species associated to this catalytic process. The complete set of data shows that FTIR measurements at the microsecond scale are clearly a key point to determine the significant chemical species leading to a fine description of the chemical mechanism.

\section{From heterogeneous catalysis to solid-state physics concepts}

A research in heterogeneous catalysis in collaboration with colleagues from industry, namely PSA Peugeot-Citroën, has formed a bridge between surface science and solid-state physics. The starting point of this research was in a publication by F. Garin regarding the interaction of a small molecule, namely $\mathrm{NO}$, and a nanometer-scale metallic cluster of $\mathrm{Pt}$ [50,51]. The most striking result was the growth of the platinum particles under NO (Figure $10)$.

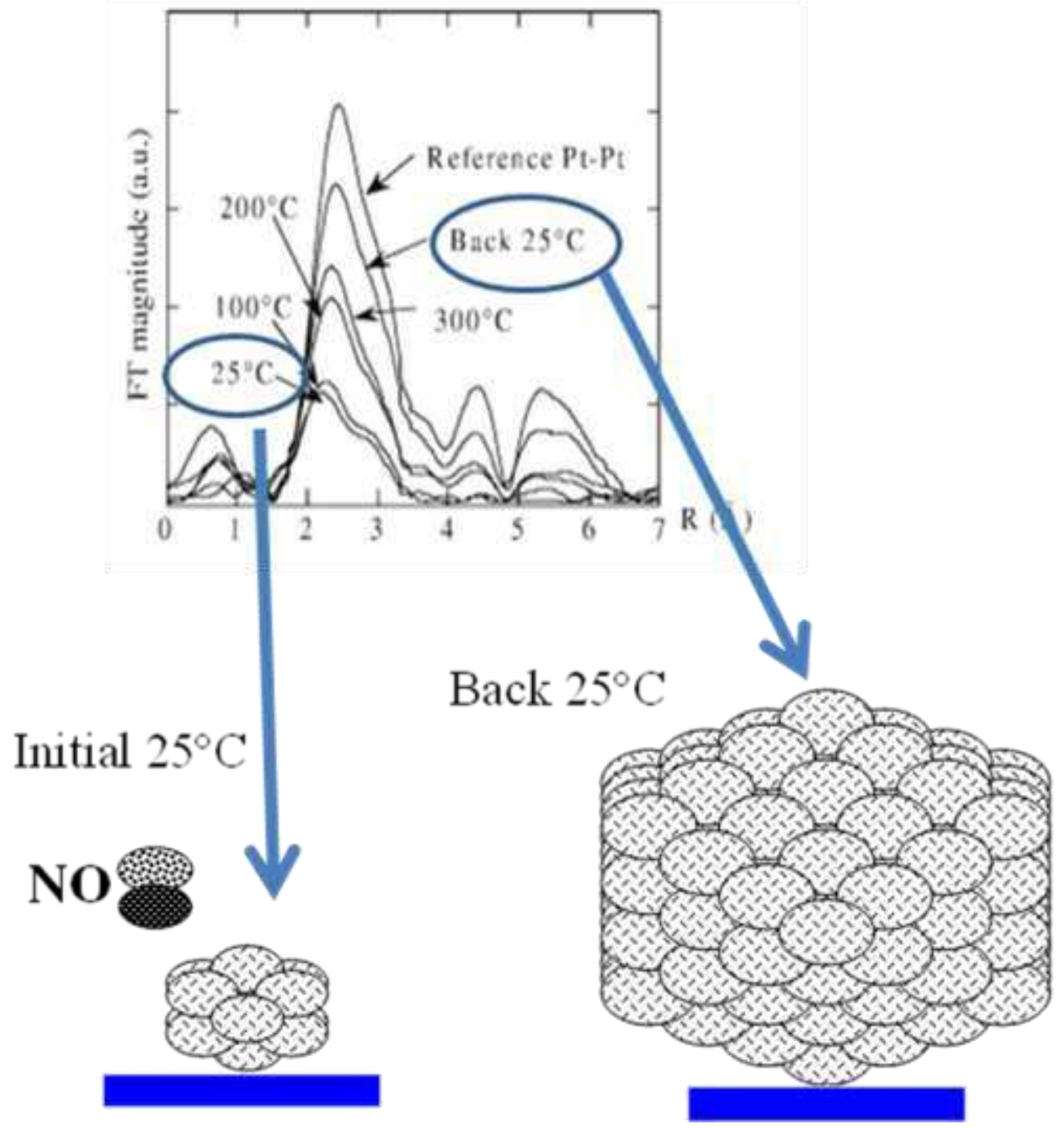

Fig. 10. Comparison of the FT magnitude of the reduced catalyst measured under hydrogen at $25^{\circ} \mathrm{C}$, under $\mathrm{NO}$ at 100,200 , and $300^{\circ} \mathrm{C}$, and back to $25^{\circ} \mathrm{C}$ with the $\mathrm{Pt}$ foil reference.

From these publications [50,51], a simple relationship (Figure 11) between the adsorption mode of NO (dissociative and molecular) and the behaviour of the nanometerscale monometallic clusters (sintering or dissociation) has been suggested [198-204]. Note that the behaviour of $\mathrm{Cu}$ [205], $\mathrm{Ru}[206], \mathrm{Rh}[207], \operatorname{Ir}[208]$, and $\mathrm{Pt}[50,51,209]$ are in line with 
this simple energetic model, the relationship being independent of the preparation procedure as well as the nature of the support. Regarding Pd[210], the effect of support is quite important and the adsorption mode of NO as well as the behaviour of nano Pd clusters may vary. The case of a sample made of Pd nanoclusters deposited on different support may be quite interesting.

Moreover, one of the striking points of this simple model is related to the possibility of using this simple model to predict the behaviour of the metal nanoparticles when considering a mixture. In that case, a straight line is defined for each mixture (Fig. 11). We may assume that if we consider adding $\mathrm{O}_{2}$ to $\mathrm{NO}$ the straight line is going down. In the case of $\mathrm{C}_{3} \mathrm{H}_{6}(500$ $\mathrm{ppm})+\mathrm{O}_{2}\left(14 \%\right.$ ) (balance $\mathrm{N}_{2}$ ), there is persistence of $\mathrm{Pt}-\mathrm{Pt}$ bonding. Thus, the presence of propene in the mixture seems to be responsible of this passivation to oxidation.
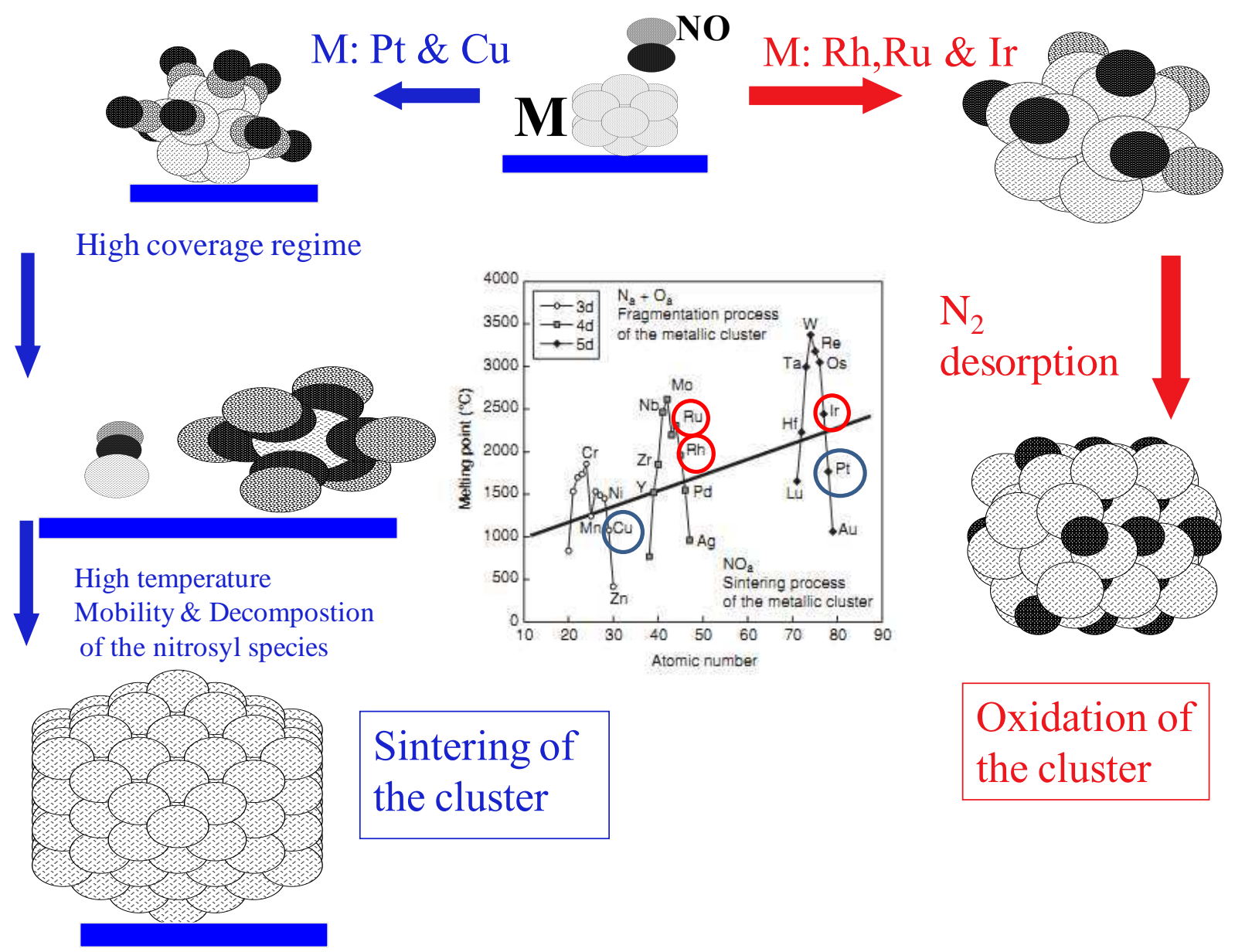

\section{Sintering of} the cluster

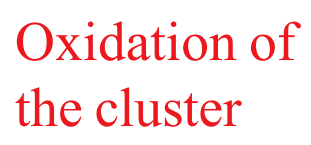

Fig. 11. Diagram of a suggested association of the adsorption mode and behaviour of metallic clusters. The thick straight line represents the frontier between dissociative adsorption with fragmentation (above the line) and associative adsorption with sintering (below the line).

Is it possible to select some bi-metallic catalysts? This purely energetic model leads to a complete rejection of some bimetallic systems [201,202]. For example, if we consider a $\mathrm{RhRu}$ bimetallic cluster (or a RhIr as well as RuIr bimetallic), the NO adsorption process leads probably to the formation of a metal oxide i.e. the dissociation of $\mathrm{NO}$ will stop. On the other hand, if we consider a $\mathrm{PtCu}$ system, it is probable that the NO adsorption will lead to large clusters. A guideline for the choice of the bimetallic system is to add a second metal such $\mathrm{Rh}$ or $\mathrm{Ru}$ to $\mathrm{Pt}$. 
As show by different excellent publications, the fact that ab initio calculations constitute now major tools in heterogeneous catalysis will improve our understanding of heterogeneous catalytic processes[211-216].

\section{Conclusions and perspectives}

This quick description of the research of F. Garin is far from being exhaustive and does not cover recent publications [217-222]. It is quite clear that since the very first investigations in heterogeneous catalysis performed by F. Garin [52], numerous major scientific breakthroughs have been published [see for example 222-233]. Thanks to the investigations of F. Thibault-Starzyk et al. [197] regarding the acquisition time and J.D. Grunwaldt on the spatial heterogeneity of chemical reactions [164], such investigations help the scientific community to precise the acquisition procedure defined by F. Garin [52]. To note, if different techniques such as FTIR spectroscopy or mass spectroscopy give quite interesting information on the reaction, as underlined by F. Garin [11-16], the use of labelled compounds still constitutes a unique way to describe in detail such associated mechanisms. For example, major information regarding isomerization of 2-methylpentane and ring opening of methylcyclopentane [14] can be obtained and the review of F. Garin on the mechanism of $\mathrm{NO}_{\mathrm{x}}$ decomposition clearly assesses many advantages of the use of labelled compounds [11].

In conclusion, I am very grateful for F. Garin's influence on my past, present and future studies, and I send him my best wishes for the future. 
References

[1] D.E. Sayers, E.A. Stern, F.W. Lytle, Phys. Rev. Lett. 27 (1971) 1204.

[2] F.W. Lytle, D.E. Sayers, E.A. Stern, Phys. Rev B 11 (1975) 4825.

[3] J.H. Sinfelt, Bimetallic Catalysts: Discoveries, Concepts and Applications (Wiley, 1983).

[4] L. J. Giovanetti, J. M. Ramallo-López, M. Foxe, L. C. Jones, M. M. Koebel, G. A. Somorjai, A. F. Craievich, M. B. Salmeron, F. G. Requejoshape, Small 8(2012) 468.

[5] M. Boudart, RA Della Betta, K Foger, DG Löffler, MG Samant, Science 228 (1985) 717.

[6] B.S. Clausen, H. Topsoe, R. Frahm, Advances in Catalysis 42(1988) 315.

[7] N. Weiher, E. Bus, B. Gorzolnik, M. Möller, R. Prins, J. A. Van Bokhoven, J. of Syn. Rad. 12(2005)675.

[8] L. Guczi, D. Bazin, App. Cat. A 188 (1999) 163.

[9] F. Garin, G. Maire, J. of Mol. Cat. 52 (1989) 147.

[10] F. Garin, S. Aeiyach, P. Légaré, G. Maire, J. of Cat. 77 (1982) 323.

[11] F. Garin, App. Cat. A 222 (2001) 183.

[12] F. Garin, Cat. To day 89 (2004) 255.

[13] F. Garin, P. Girard, S. Ringler, G. Maire, N. Davias, App. Cat. B 20 (1999) 205.

[14] F. Garin, P. Girard,G. Maire, G. Lu, L. Guczi, App. Cat. A 152 (1997) 237.

[15] F. Garin, P. Girard, S. Ringler, G. Maire, N. Davias, App. Cat. B 20 (1999) 205.

[16] F. Garin, O. Zahraa, C. Crouzet, J.L. Schmitt, G. Maire, Surf. Sci. 106 (1981) 466.

[17] H. Fricke, Phys. Rev. 16 (1920) 202.

[18] Y. Cauchois, N.F. Mott, Philos. Mag. 40(1949) 1260.

[19] A. Borgna, T.F. Garetto, C.R. Apesteguõ, B. Moraweck, App. Cat. A 182 (1999) 189.

[20] I Davoli, S Stizza, A Bianconi, M Benfatto, C Furlani, V Sessa, Solid State Communications 48 (1983) 475.

[21] H. Yoshida, Y. Yazawa, T. Hattori, Cat. Today 87 (2003)19.

[22] T. B. Bolin, T. Wu, N.Schweitzer, R. Lobo-Lapidus, A. J. Kropf, H.Wang, Y. Hu, J.T. Miller, S.M. Heald, Cat. Today, In Press.

[23] E. Becker, P.-A. Carlsson, H. Grönbeck, M. Skoglundh, J. of Cat. 252 (2007) 11.

[24] V.P. de Souza, D. Costa, D. dos Santos, A.G. Sato, J.M.C. Bueno, Int. J. of Hydrogen Energy 37 (2012) 9985.

[25] F. Behafarid, L.K. Ono, S. Mostafa, J.R. Croy, G. Shafai, S. Hong, T.S. Rahman, S.R. Bare, B.R. Cuenya, Phys. Chem. Chem. Phys. 14 (2012) 11766.

[26] G.N. Greaves, P.J. Durham, G. Diakun, P. Quinn, Nature 294 (1981) 139.

[27] D. Bazin, J. Rehr, J. Phys. Chem C 115 (2011) 23233.

[28] D. Bazin, D. Sayers, J. J. Rehr, C. Mottet, J. Phys. Chem B 101 (1997) 5332.

[29] D. Bazin, J. Lynch, M. Ramos-Fernandez, Oil \& Gas Science and Technology - Rev. IFP 58 (2003) 667.

[30] J. Moonen, J. Slot, L. Lefferts, D. Bazin, H. Dexpert, Physica B 208(1995) 689.

[31] R.B. Greegor, F.W. Lytle, J. of Cat. 63 (1980) 476.

[32] D. Bazin, L. Guczi, App. Cat. 213 (2001) 147.

[33] R. Revel, D. Bazin, Ph. Parent, C. Laffon, Cat. Let. 74 (2001) 189.

[34] R. Revel, D. Bazin,A.M. Flank, J. Syn. Rad. 6 (1999) 717.

[35] D. Bazin, J. Rehr, Cat. Let. 87 (2003) 85.

[36] J. Lynch, G. Everlien, C. Leblond, D. Bazin, J. of Syn. Rad. 6 (1999) 661.

[37] D. Bazin,I. Kovacs, L. Guczi, P. Parent, C. Laffon, F. De Groot, O. Ducreux, J. Lynch, J. of Cat. 189 (2000) 456.

[38] F. Zheng, S. Alayoglu, J. Guo, V. Pushkarev, Y. Li, P.-A. Glans, J. L Chen, G. Somorjai Nano Lett. 11 (2011) 847.

[39] T. Herranz, X. Deng, A. Cabot, J. Guo,M. Salmeron, J. Phys. Chem. B, 113 (2009) 10721.

[40] A. M. Saib, A. Borgna, J. van de Loosdrecht, P. J. van Berge, J. W. Niemantsverdriet J. Phys. Chem. B 110 (2006) 8657.

[41] G. Plazenet, E. Payen, J. Lynch, B. Rebours, J. Phys. Chem. B 106 (2002) 7013.

[42] A. Knop-Gericke, M. Hävecker, T. Schedel-Niedrig, R. Schlögl Top. Catal. 10 (2000) 187. 
[43] S. Carenco, A. Tuxen, M. Chintapalli, E. Pach, C. Escudero, T. D. Ewers, P. Jiang,

F. Borondics, G. Thornton, P. Alivisatos, H. Bluhm, J. Guo, M. Salmeron

J. Phys. Chem. C 117 (2013) 6259.

[44] P. Lagarde, H. Dexpert, Adv. Phys. 33 (1984) 567.

[45] D. Bazin, H. Dexpert, P. Lagarde, Topics in Current Chemistry 145 (1988) 69.

[46] F.W. Lytle, J. Syn. Rad. 6 (1999) 123.

[47] J.J. Rehr, A.L. Ankudinov, Coordination Chemistry Reviews 249 (2005) 131.

[48] D. Bazin, L. Guczi, App. Cat. A 213 (2001) 147.

[49] E. A. Stern, D. E. Sayers, J. G. Dash, H. Shechter, B. Bunker, Phys. Rev Lett. 38 (1977) 767.

[50] S. Schneider, D. Bazin, F. Garin, G. Maire, M. Capelle, G. Meunier, R. Noirot, App. Cat. A 189 (1999) 139.

[51] S. Schneider, D. Bazin, G. Meunier, R. Noirot , M. Capelle, F. Garin, G. Maire, Cat. Let. 71 (2001) 155.

[52] G. Maire, F. Garin, P. Bernhardt, P. Girard, J.L. Schmitt, E. Dartyge, H. Dexpert, A. Fontaine, A. Jucha, P. Lagarde, App. Cata. 26 (1986) 305.

[53] P. Esteban Puges, F. Garin, F. Weisang, P. Bernhardt, P. Girard, G. Maire, L. Guczi, Z. Schay, J. of Cat. 114 (1988) 153.

[54] V. Pitchon, F. Garin, G. Maire, App. Cat. A 149 (1997) 245.

[55] P. Bourges, F. Garin, G. Maire, G. Szabo, M. Laborde, R. Loutaty, D. Bazin J. Phys. IV France C4-06 (1996) 947

[56] F. Maire, M. Capelle, G. Meunier, J.F. Beziau, D. Bazin, H. Dexpert, F. Garin, J.L. Schmitt, G. Maire, Studies in Surface Science and Catalysis, 96 (1995) 749.

[57] F. Garin, S. Aeiyach, P. Legare, G. Maire, J. of Cat. 77 (1982) 323.

[58] A. Dauscher, F. Garin, G. Maire, J. of Cat. 105 (1987) 233.

[59] B. Moraweck, A.J. Renouprez, Surf. Sci. 106 (1981) 35.

[60] P. Lagarde, F. Murata, G. Vlaic, E. Freund, H. Dexpert, J.P. Bournonville, J. Cat. 84(1983) 333.

[61] D. Bazin, H. Dexpert, J.P. Bournonville, J. Lynch, J. of Cat. 123 (1990) 86.

[62] D. Bazin, H. Dexpert, P. Lagarde, J.P. Bournonville, J. of Cat. 110 (1988) 209.

[63] D. Bazin, A. Triconnet, P. Moureaux, NIM B 97(1995) 41.

[64] R.L. Gasten, J.H. Sinfelt, J. of Cat. 62(1980)127.

[65] K. Asakura, W.J. Chun, M. Shirarai, K. Tomishige, Y. Iwasawa, J. Phys. Chem. B, 10 (1997) 5549.

[66] D. Bazin, J. Rehr, Cat. Let. 87 (2003) 85.

[67] J.J Rehr, R.C. Albers, Phys. Rev. B 41 (1990) 8149.

[68] M.G. Samant, G. Bergeret, G. Meitzner, P. Gallezot, M. Boudart, J. Phys. Chem. 92(1988) 3542.

[69] D. Bazin, D. Sayers, J.J. Rehr, J. Phys. Chem. B 101 (1997) 11040.

[70] U.S. Jeng, Y.H. Lai, H.S. Sheu, J.F. Lee, Y.S. Sun, W.T. Chuang, Y.S. Huang, D.G. Liu, J. App. Crys. 40 (2007) S418.

[71] K. Pirkkalainen, U. Vainio, K. Kisko, T. Elbra, T. Kohout, N.E. Kotelnikova, R. Serimaa, J. App. Cryst. 40 (2007) S489.

[72] D. Bazin, L. Guczi, J. Lynch App. Cat A 226(2002)87.

[73] O. Ducreux, B. Rebours, J. Lynch, M. Roy-Auberger, D. Bazin, Oil \& Gas Science and Technology - Rev. IFP 64 (2009) 49.

[74] M. Ronning, N.E. Tsakoumis, A. Voronov, R.E. Johnsen, P. Norby, W. van Beek, O. Borg, E. Rytter, A. Holmen, Cat Today 155 (2010) 289.

[75] R. Revel, D. Bazin, H. Dexpert, E. Elkaim, A. Seigneurin, J. Phys. Chem. B 104 (2000) 9828.

[76] D. Bazin, R. Revel, J. of Syn. Rad. 6 (1999) 483.

[77] D. Bazin, D. Sayers, Jpn. J. Appl. Phys. 32-2 (1993) 249.

[78] D. Bazin, D. Sayers, Jpn. J. Appl. Phys. 32-2 (1993) 251.

[79] A.V. Klein, T.W. Hambley, Chem. Rev. 109(2009) 4911.

[80] S. Chen, Y. Wu, S. Tao, P. Cui, W. Chu, X. Chen, Z. Wu, J. of Mol. Struc. 1041 (2013) 39.

[81] H. Guesmi, P. Massiani, Cat. Today, 177 (2011) 25.

[82] S. Dzwigaj, J.Janas, J. Gurgul,R.P. Socha,T. Shishido, M. Che, App. Cat. B 85 (2009)131.

[83] C.E. Hédoire, E. Cadot, F. Villain, A. Davidson, C. Louis, M. Breysse, 
App. Cat. A 306 (2006)165.

[84] S. Chouzier, T. Czeri, M. Roy-Auberger, Ch. Pichon, Ch. Geantet, M. Vrinat, P. Afanasiev J. of Solid State Chemistry, 184 (2011) 2668.

[85] J. Blanchard, K. K. Bando, M. Breysse, Ch. Geantet, M. Lacroix, Y. Yoshimura Cat. Today 147 (2009) 255.

[86] B. Guichard, M. Roy-Auberger, E. Devers, C. Pichon, C. Legens, App. Cat. A 367(2009)9.

[87] N. Frizi, P. Blanchard, E. Payen, P. Baranek, M. Rebeilleau, C. Dupuy, J.- P. Dath Cat. Today, 130 (2008) 272.

[88] H. Loboué, C. Guillot-Deudon, A. F. Popa, A. Lafond, B. Rebours, Ch. Pichon, T. Cseri, G. Berhault, Ch. Geantet, Cat. Today, 130(2008) 63.

[89] D. Bouvet, A. Michalowicz, S. Crauste-Manciet, E. Curis, I. Nicolis, L. Olivi, G. Vlaic, D. Brossard, K. Provost, J. Syn. Rad.13 (2006) 477.

[90] E. Curis, K. Provost, I. Nicolis, D. Bouvet, S. Benazeth, S. Crauste-Manciet, F. Brion, D. Brossard, New J. Chem. 24 (2000) 1003.

[91] D. Bouvet, A. Michalowicz, S. Crauste-Manciet, D. Brossard, K. Provost Inorg. Chem. 45 (2006) 3393.

[92] E. C. Beret, K. Provost, D. Müller, E. Sanchez Marcos, J. Phys. Chem. B 113 (2009) 12343.

[93] A. Bensaddik, A. Caballero, D. Bazin, H. Dexpert, B. Didillon, J. Lynch, App. Cat. A 162(1997) 171.

[94] A. Bensaddik, H. Dexpert, D. Bazin, A. Caballero, F. Villain, B. Didillon, J. Lynch, Physica B 208 (1995) 677.

[95] S. Gómez-Ruiza, G. N. Kaluđerović, D. Polo-Ceróna, V. Tayurskaya, S. Prashara, M. Fajardo, R. Paschke, J. of Organomet. Chem. 694 (2009) 3032.

[96] S. Benazeth, D. Bazin, B. Viossat, H. Dexpert, P. Laruelle, N.H. Dung, J. de chimie Physique et de physico-chimie biologique 86 (1989)1635.

[97] M.D. Hall, G.J. Foran, M. Zhang, P.J. Beale, T.W. Hambley, J. Am. Chem. Soc. 125 (2003) 7524.

[98] E. F. Molina, S. H. Pulcinelli, C. V. Santilli, V. Briois, J. Phys. Chem. B 116 (2012) 7931.

[99] D. Bazin, P . Chevallier, G. Matzen, P. Jungers, M. Daudon, Urol. Res. 35 (2007) 179

[100] D. Bazin, Ch. Chappard, C. Combes, X. Carpentier, S. Rouzière, G. André, G. Matzen, M. Allix, D. Thiaudière, S. Reguer, P. Jungers, M. Daudon, Osteop. Int. 20 (2009) 1065.

[101] D. Bazin, X. Carpentier, I. Brocheriou, P. Dorfmuller, S. Aubert, Ch. Chappard, D. Thiaudière, S. Reguer, G. Waychunas, P. Jungers, M. Daudon, Biochimie 91 (2009) 1294.

[102] X. Carpentier, D. Bazin, Ch. Combes, A. Mazouyes, S. Rouzière, P. A. Albouy, E. Foy, M. Daudon, J. of Trace Elements in Medicine and Biology 25 (2011) 160.

[103] D. Bazin, M. Daudon, Ch. Chappard, J.J. Rehr, D. Thiaudière, S. Reguer, J. of Syn. Rad. 18 (2011) 912.

[104] D. Bazin, M. Daudon, C. Combes, C. Rey, Chem. Rev. 112 (2012) 5092.

[105] D. Bazin, M. Daudon, J. Phys. D : Appl. Phys. 45 (2012) 383001.

[106] A. Dessombz, P. Méria, D. Bazin, M. Daudon, Plos One 7 (2012) e51691.

[107] D. Bazin, G. André, R. Weil, G. Matzen, E. Véron, X. Carpentier, M. Daudon, Urology 79 (2012) 786.

[108] M. Daudon, D. Bazin, J. of Physics: Conference Series 425 (2013) 022006.

[109] H.-K. Ea, V. Chobaz, Ch. Nguyen, S. Nasi, P. van Lent, M. Daudon, A. Dessombz, D. Bazin, G. McCarthy, B. Jolles-Haeberli, A. Ives, D. Van Linthoudt, A. So, F. Lioté, N. Busso, Plos One 8 (2013) e57352.

[110] A. Dessombz, Ch. Nguyen, H.K. Ea, S. Rouziere, E. Foy, D. Hannouche, S. Reguer, F.E. Picca, D. Thiaudière, F. Lioté, M. Daudon, D. Bazin, J. of Trace elements in medicine and biology, 27 (2013) 326.

[111] www.synchrotron-soleil.fr/

[112] http://www.synchrotron-soleil.fr/Recherche/LignesLumiere/DIFFABS

[113] D. Bazin, X. Carpentier, O. Traxer, D. Thiaudière, A. Somogyi, S. Reguer, G. Waychunas, P. Jungers, M. Daudon, J. of Syn. Rad. 15 (2008) 506.

[114] S. Hasnain, J. of Syn. Rad. 14 (2007) 297. 
[115] S.R. Bare, N. Yang, S.D. Kelly, G.E. Mickelson, F.S. Modica, Catal. Today 126 (2007) 18.

[116] F.W. Lytle, P.S.P. Wei, R.B. Greegor, G.H. Via, J. H. Sinfelt, J. Chem. Phys. 70 (1979) 4849.

[117] F.W.H. Kampers, T.M.J. Maas, J. van Grondelle, P. Brinkgreve, D.C. Koningsberger, Rev. Sci. Instrum. 60 (1989) 2635.

[118] B. S. Clausen, G. Steffensen, B. Fabius, J. Villadsen, R. Feidenhansl, H. Topsoe, J. Catal. 132 (1991) 524.

[118] A.J. Dent, G.N. Greaves, M.A. Roberts, G. Sankar, P.A. Wright, R.H. Jones, M. Sheehy, D. Madill, C.R.A. Catlow, J.M. Thomas, T. Rayment, Nucl. Instrum. Methods Phys. Res., Sect. B 97 (1995) 20.

[119] G. Meitzner, S.R. Bare, D. Parker, H. Woo, D.A. Fischer, Rev. Sci. Instrum. 69 (1998) 2618.

[120] R. Revel, D. Bazin, A. Seigneurin, P. Barthe, J.M. Dubuisson, T. Decamps, H. Sonneville, J.J. Poher, F. Maire, P. Lefrançois, Nucl. Instrum. Methods Phys. Res., Sect. B 155 (1999) 183.

[121] I. Pettiti, D. Gazzoli, M. Inversi, M. Valigi, S. De Rossi, G. Ferraris, P. Porta, S. Colonna, J. Syn. Rad. 6 (1999) 1120.

[122] S. Schneider, D. Bazin, J. M. Dubuisson, M. Ribbens, H. Sonneville, G. Meunier, F. Garin, G. Maire, H. Dexpert, J. of X-Ray Science and Technology 8 (2000) 221.

[123] A. J. Berry, J. M. G. Shelley, G. J. Foran, H. S. C. O'Neill, D. R. Scott, J. Syn. Rad. 10 (2003) 332.

[124] J.-S. Girardon, A. Y. Khodakov, M. Capron, S. Cristol, C. Dujardin, F. Dhainaut,S. Nikitenko, F. Meneau, W. Bras, E. Payen, J. Syn. Rad. 12 (2005) 680.

[125] S. Hannemann, M. Casapu, J.-D. Grunwaldt, P. Haider, P. Trüssel, A. Baiker, E. Welter, J. Syn. Rad. 14 (2007) 345.

[126] G. Guilera, B. Gorges, S. Pascarelli, H. Vitoux, M. A. Newton, C. Prestipino, Y. Nagai N. Hara, J. Syn. Rad. 16 (2009) 628.

[127] M. Bauer, G. Heusel, S. Mangold, H. Bertagnolli, J. Syn. Rad. 17 (2010) 273.

[128] J.J.H.B. Sattler, I.D. Gonzalez-Jimenez, A.M. Mens, M. Arias, T. Visser, B.M. Weckhuysen, Chem. Com. 49(2013)1518.

[129] N.S. Guyot-Sionnest, F. Villain, D. Bazin, H. Dexpert, F. Lepeltier, J. Lynch, J.P. Bournonville, Cat. Let. 8 (1991) 283.

[130] N.S. Guyot-Sionnest, F. Villain, D. Bazin, H. Dexpert, F. Lepeltier, J. Lynch, Cat. Let. 8 (1991) 297.

[131] J.-D. Grunwaldt, L. Basini, B.S. Clausen, J. of Cat. 200 (2001) 321.

[132] J.-D. Grunwaldt, M. Maciejewski, A. Baiker, Phys. Chem. Chem. Phys., 5 (2003) 1481.

[133] J.-D. Grunwaldt, C. Keresszegi, T. Mallat, A. Baiker, J. Catal. 225 (2004) 138.

[134] C. Keresszegi, J.-D. Grunwaldt, T. Mallat, A. Baiker, J. Catal. 222 (2004) 268.

[135] M. Caravati, J.-D. Grunwaldt, A. Baiker, Catal. Today 91-92 (2004) 1

[136] J.-D. Grunwaldt, M. Caravati, A. Baiker, J. Phys. Chem. B 110 (2006) 9916.

[137] J.-D. Grunwaldt, M. Caravati, A. Baiker, J. Phys ; Chem B Letters 110 (2006) 25586.

[138] B. Kimmerle, J.-D. Grunwaldt, A. Baiker, P. Glatzel, P. Boye, S. Stephan, C.G. Schroer, J. Phys Chem B Letters 113 (2009) 3037.

[139] E. Dartyge, A. Fontaine, G. Tourillon, R. Cortes, A. Jucha, Physics Letters A 113 (1986) 384.

[140] E. Dartyge, C. Depautex, J.M. Dubuisson, A. Fontaine, A. Jucha, P. Leboucher, G. Tourillon, NIM B 246 (1986) 452.

[141] D.E. Sayers, D. Bazin, H. Dexpert, A. Jucha, E. Dartyge, A. Fontaine, P. Lagarde, Physica B 158 (1989) 206.

[142] D. Bazin, H. Dexpert, J.P. Bournonville, J. Lynch, J. of Cat. 123(1990) 89.

[143] J.W. Couves, J.M. Thomas, C.R.A. Catlow, G.N. Greaves, G. Baker, A.J. Dent, J. Phys. Chem. 94 (1990) 6517.

[144] G. Sankar, J.M. Thomas, D. Waller, J.W. Couves, C.R.A. Catlow, G.N. Greaves, J. Phys. Chem. 96 (1992) 7485.

[145] J.M. Thomas, G.N. Greaves, Science 265 (1994) 1675.

[146] D. Ferri, M. S. Kumar, R. Wirz, A.Eyssler, O. Korsak, P.Hug, A. Weidenkaff, M. A. Newton, Phys. Chem. Chem. Phys. 12 (2012) 5634.

[147] S. Pascarelli, O. Mathon, Phys. Chem. Chem. Phys. 12 (2010) 5535.

[148] M. A. Newton, A. J. Dent, J. Evans, Chem. Soc. Rev. 31(2002) 83. 
[149] S. Adora, Y. Soldo-Olivier, R. Faure, R. Durand, E. Dartyge, F. Baudelet J. Phys. Chem. B 105 (2001)10489.

[150] http://www.synchrotron-soleil.fr/Recherche/LignesLumiere/SAMBA

[151] A. Rochet, V. Moizan, C. Pichon, F. Diehl, A. Berliet, V. Briois, Cat. Today 171 (2011) 186.

[152] C. La Fontaine, L. Barthe, A. Rochet, V. Briois, Cat To day in press.

[153] http://www.synchrotron-soleil.fr/Recherche/LignesLumiere/ODE

[154] Q. Kong, F. Baudelet, J. Han, S. Chagnot, L. Barthe, J. Headspith, R. Goldsbrough, F. E. Picca, O. Spalla, Scientific Reports 2 (2013) 1018.

[155] G. Ouvrard, M. Zerrouki, P. Soudan, B. Lestriez, Ch. Masquelier, M. Morcrette, S. Hamelet, S. Belin, A. M. Flank, F. Baudelet, J. of Power Sources 229 (2013) 16.

[156] C. Prieto, P. Parent, F. Le Normand, P. Lagarde, H. Dexpert, in: A. Balerna, A. Bernieri, S. Mobilio (Eds.), Proceedings of the Second European Conference on the Progress of X-ray Synchrotron Radiation Research, Italian Physics Society, Bologna, 1990, p. 411.

[157] A.J. Dent, M. Oversluizen, G.N. Greaves, M.A. Roberts, G. Sankar, C.R.A. Catlow, J.M. Thomas, Physica B: Condensed Matter 208-209 (1995) 253.

[158] M. Epple, U. Sazama, A. Reller, N. Hilbrandt, M. Martin, L. Troger, Chem. Commun. (1996) 1755.

[159] F. Cimini, R. Prins, J. Phys. Chem. B 101 (1997) 5277.

[160] J.-D. Grunwaldt, D. Lützenkirchen-Hecht, M. Richwin, S. Grundmann, B. S. Clausen, R. Frahm, J. Phys. Chem. B 105 (2001) 5161.

[161] J. Evans, L. O’Neill, V. L. Kambhampati, G. Rayner, S. Turin, A. Genge, A.J. Dent, Th. Neisius, J. Chem. Soc., Dalton Trans., 2002, 2207-2212

[162] D. Nicosia, R. Prins, J. of Cat. 231(2005)259.

[163] S. Nikitenko, A. M. Beale, M. J. Van Der Eerden, S. D. M. Jacques, O. Leynaud, M.G. O'Brien, D. Detollenaere, R. Kaptein, B.M. Weckhuysen, W. Bras, J. of Syn. Rad. 15(2008) 632.

[164] J.D. Grunwaldt, M. Beier, B. Kimmerle, A. Baiker, M. Nachtegaal, B. Griesebock, D. Lützenkirchen-Hecht, J. Stötzeld, R. Frahm, Phys. Chem. Chem. Phys. 11 (2009) 8779.

[165] S. A. Bartlett, P. P. Wells, M. Nachtegaal, A.J. Dent, G. Cibin, G. Reid, J. Evans, M. Tromp J. of Cat. 284 (2011) 247.

[166] J. Stötzel, R. Frahm, B. Kimmerle, M. Nachtegaal, J. D. Grunwaldt J. Phys. Chem. C 116 (2012) 599.

[167] T. Wada, K.K. Bando, T. Miyamoto, S. Takakusagi, S. T. Oyama, K. Asakura, J. of Syn. Rad. 19(2012) 205.

[168] T.A. Nguyen, S. Loridant, L. Chantal, T. Cholley, Ch. Geantet, App. Cat. B 107 (2011) 59.

[169] R. Frahm, NIM B 270 (1988) 578.

[170] W. Yu, M. D. Porosoff, J.G. Chen, Chem. Rev. 112 (2012) 5780.

[171] A. I. Frenkel, Chem. Soc. Rev. 41 (2012) 8163.

[172] H. Wang, W. Zhou, J.-X. Liu, R. Si, G. Sun, M.-Q. Zhong, H.-Y. Su, H.-B. Zhao, J. A. Rodriguez, S. J. Pennycook, J.-C. Idrobo, W.-X. Li, Y. Kou, D. Ma, J.A.C.S. in press.

[173] L. Guczi, D. Bazin, I. Kovacs, L. Borko, Z. Schay, J. Lynch, P. Parent, C. Lafon, G. Stefler, Zs. Koppany, I. Sajo, Topics in Catalysis 20 (2002) 129.

[174] X.Wang, N. Li, L.D. Pfefferle, G.L. Haller, J. Phys. Chem. C 114 (2010) 16996.

[175] S. M. Oxford, P. L. Lee, P. J. Chupas, K. W. Chapman,M. C. Kung, H.H. Kung, J. Phys. Chem. C 114 (2010) 17085.

[176] A. Lehoux, L. Ramos, P. Beaunier, D. B. Uribe, Ph. Dieudonné, F. Audonnet, A. Etcheberry, M. José-Yacaman, H. Remita, Adv. Funct. Mater. 22 (2012) 4900.

[177] D. Bazin, D. Guillaume, C. Pichon, D. Uzio, S. Lopez, Oil \& Gas Science and technology 60 (2005) 801.

[178] D. Bazin, A. Triconnet, P. Moureaux, NIM B 97(1995) 41.

[179] C.J. Weststrate, A.M. Saib, J.W. Niemantsverdriet, Catalysis Today 215 (2013) 2.

[180] F. Hilbrig, Ch. Michel, G. L. Haller, J. Phys. Chem. 96 (1992) 9893.

[181] M. C. Román-Martínez, J. A. Maciá-Agulló, I. Ma, J. Vilella, D. Cazorla-Amorós, H. Yamashita, J. Phys. Chem. C 111 (2007) 4710. 
[182] P. Dash, T. Bond, C. Fowler, W. Hou, N. Coombs, R. W. J. Scott, J. Phys. Chem. C 113 (2009) 12719.

[183] J. Wang, P.A. Chernavskii, A.Y. Khodakov, Y. Wang, J. of Catalysis 286 (2012) 51.

[184] I.H. Jang, S.H. Uma, B. Lim, M.H. Woo, K.-W. Jun, J.-B. Lee, J.W. Bae, Applied Catalysis A: General 450 (2013) 88.

[185] H. Ziaei-azad, C.-X. Yin, J. Shen, Y. Hu, D. Karpuzov, N. Semagin, J. of Catalysis 300 (2013) 113.

[186] M. Rønning, N.E. Tsakoumis, A. Voronov, R.E. Johnsen, P. Norby, W. van Beek, Ø. Borg, E. Rytter, A. Holmen, Cat. Today 155 (2010) 289.

[187] Ch. Geantet, Y. Soldo, CL Glasson, N. Matsubayashi, M. Lacroix, O. Proux, O. Ulrich, J.L. Hazemann, Cat. Let. 73 (2001) 95.

[188] C. Thomazeau, C. Geantet, M. Lacroix, M. Danot, V. Harle Oil \& Gas Science and Technology - Rev. IFP 60 (2005) 781.

[189] D. Bazin, H. Dexpert, J. Lynch, J.P. Bournonville, J. Syn. Rad. 6 (1999) 465.

[190] A. Bensaddik, A. Caballero, D. Bazin, H. Dexpert, B. Didillon, J. Lynch, Applied Catalysis A 162 (1997) 171.

[191] S. Pizzini, F. Baudelet, E. Dartyge, A. Fontaine, Ch. Giorgetti, J.F. Bobo, M. Piecuch, C. Marlière, J. of Magnetism and Magnetic Materials 121 (1993) 208.

[191] L. Douillard, M. Gautier-Soyer, J.P. Duraud, A. Fontaine, F. Baudelet J. of Physics and Chemistry of Solids 57 (1996) 495.

[192] M.A. Newton, A.J. Dent, S.G. Fiddy, B. Jyoti, J. Evans, Catalysis Today 126 (2007) 64.

[193] S. K. Matam, M.A. Newton, A. Weidenkaff, D. Ferri, Cat. Today 205 (2013) 3.

[194] Y. Lu, K.A. Michalow, S. K. Matama, A. Winkler, A.E. Maeglia, S. Yoona, A. Heele, A. Weidenkaffa, D. Ferri, Applied Catalysis B: Environmental 144 (2014) 631

[195] I.M. Lane, D. A. King, Z. P. Liu, H. Arnolds, Phys. Rev. Lett. 9 (2006) 6105.

[196] H. Arnolds, D. A. King, I. M. Lane, Chem. Phys. 350 (2008) 94.

[197] F. Thibault-Starzyk, E. Seguin, S. Thomas, M. Daturi, H. Arnaolds, D.A. King Science 324 (2009) 1048.

[198] D. Bazin, Top. Catal. 18 (2002) 79.

[199] D. Bazin, D. Sayers, J. Lynch,L. Guczi,G. Tréglia, C. Mottet, Oil Gas Sci. Technol.-Rev. IFP 6 (2006) 67.

[200] D. Bazin, C. Mottet, G. Tréglia, J. Lynch, App. Surf. Science 164 (2000) 140.

[201] D. Bazin, C. Mottet, G. Treglia, App. Cat. A 200 (2000) 47.

[202] D. Bazin, Macromolecular Research 14 (2006) 230.

[203] D. Bazin, M. Daudon, J. Phys. D : Appl. Phys. 45 (2012) 383001

[204] J. Friedel, Private communications

[205] S. Haq, A. Carew, R. Raval, J. Catal. 221(2004) 204.

[206] T. Hashimoto, H. Hayashi, Y. Udagawa, A. Ueno, Physica B, 208/209(1995) 683.

[207] T. Campbell, A. J. Dent, S. Diaz-Moreno, J. Evans, S. G. Fiddy, M. A. Newton, S. Turin, Chem. Commun. (2002) 304-305

[208] C. Wögerbauer, M. Maciejewski, A. Baiker, J. Catal. 205 (2002) 157.

[209] P. Loof, B. Stenbom, H. Norden, B. Kasemo, J. Catal. 44(1993) 60.

[210] K. Højrup Hansen, Z. Sljivananin, E. Laesgsgaard, F. Besenbacher, I. Stensgaardet, Surf. Sci., 505 (2002) 25.

[211] M.C. Valero, P. Raybaud, Cat. Let. 143 (2013) 1.

[212] YH Zhao,HY Su, KJ Sun, JX Liu, W.X. Li, Surf. Sci. 606 (2012) 598.

[213] N. Balakrishnan, B. Joseph, V.R. Bhethanabotla, Surf. Sci. 606 (2012) 634.

[214] C.H. Hu, C. Chizallet, Ch. Mager-Maury, M. Corral-Valero, Ph. Sautet, H. Toulhoat, P. Raybaud, J. of Cat. 274 (2010) 99.

[215] P. Bechthold, S. Ardenghi, V. C. Schwindt, E.A. González, P.V. Jasen, V. Orazi, M.E. Pronsato, A. Juan, Applied Surface Science 282 (2013) 17.

[216] E. J. Lamas, P.B. Balbuena, J. Phys. Chem. B 107 (2003) 11682.

[217] A.Djeddi, I. Fechete, F. Garin, Cat. Comm. 17 (2012) 173.

[218] S. Haddoum, I. Fechete, B. Donnio, F.Garin, D. Lutic, C. E. Chitour, Cat. Com. 27 (2012) 141. 
[219] A. Boulaoued, I. Fechete, B. Donnio, M. Bernard, Ph. Turek, F. Garin, Microporous and Mesoporous Materials, 155 (2012) 131.

[220] A. Djeddi, I. Fechete, F. Garin, App. Cat. A: 413-414 (2012) 340.

[221] J. Klein, D. Wu, V. Tschamber, I. Fechete, F. Garin, App. Cat. B 132-133 (2013) 527.

[222] D. Bazin, I. Fechete, F. Garin, G. Barcaro, F. R. Negreiros, L. Sementa, A. Fortunelli in "Nanoalloys : From fundamentals to emergent applications", Ed. F. Calvo, Springer Serie, 2013.

[223] M. A. Newton, Chem. Soc. Rev. 37 (2008) 2644.

[224] S.R. Bare, S.D. Kelly, B. Ravel, N. Greenlay, L. King, G. E. Mickelson Phys. Chem. Chem. Phys. 12 (2010) 7702.

[225] W. Yu, M. D. Porosoff, J.G. Chen, Chem. Rev. 112 (2012) 5780.

[226] S. Bordiga, E. Groppo, G. Agostini, J.A. van Bokhoven, C. Lamberti Chem. Rev. 113 (2013) 1736.

[227] H. Wang, Wu Zhou, Jin-Xun Liu, Rui Si, Geng Sun, Meng-Qi Zhong, Hai-Yan Su, Hua-Bo Zhao, Jose A..Rodriguez, S.J. Pennycook, J.C. Idrobo, W.-X. Li, Y. Kou, D. Ma J. Am. Chem. Soc. 135 (2013) 4149.

[228] M. K. Gnanamani, G. Jacobs, W.D. Shafer, B.H. Davis, Catalysis Today 215 (2013) 13.

[229] L. Braconnier, E. Landrivon, I. Clémençon, C. Legens, F. Diehl, Y. Schuurman Catalysis Today 215 (2013) 18.

[230] D. Peña, A. Griboval-Constant, V. Lecocq, F. Diehl, A.Y. Khodakov, Catalysis Today 215 (2013) 43.

[231] G. Jacobs, W. Ma, P. Gao, B. Todic, T. Bhatelia, D. B. Bukur, B. H. Davis, Catalysis Today 214 (2013) 100.

[232] T. Jermwongratanachai, G. Jacobs, W. Ma, W. D. Shafer, M. K. Gnanamani, P. Gao, B. Kitiyanan, B.H. Davis, J.L.S. Klettlinger, C.H. Yen, D.C. Cronauer, A.J. Kropf, Ch.L. Marshall, App. Cat. A: General, In Press.

[233] F.D. Vila, J.J. Rehr, S.D. Kelly, S.R. Bare, J. Phys. Chem. C in press. 